\title{
THE IMPACT OF COVID-19: WHAT SCHOOL PRINCIPALS AS INSTRUCTIONAL LEADERS ACT?
}

\author{
Karwanto \\ Surabaya State University, Indonesia \\ Email : karwanto@unesa.ac.id
}

\begin{abstract}
Purpose: The study is conducted to determine, explain, and analyze the role of the principal as a learning leader in the Covid-19 pandemic era..

Design/methodology/approach: The research uses a qualitative approach with descriptive methods. Data are obtained through a literature review and analyzed using a qualitative descriptive approach..

Findings: The results show that (1) the principal professionally conducted dialogue and discussions about learning during the Covid-19 pandemic; (2) the principal provides an example to the teacher in terms of learning; (3) the principal maintains communication, coordination, collaboration and synergy with teachers during the implementation of the online learning process; (4) school principals monitor and evaluate learning in a planned, programmed and continuous manner and make use of the results of monitoring and evaluation for professional development.

Practical implications: In practical implementation, there are several things that the principal needs to do, namely (1) monitoring the progress of the school following the vision of the school; (2) being supportive and corrective when there are deviations in the implementation of activities that do not lead to the school's image; (3) monitoring and evaluating the management of the work structure of teachers and students; (4) increasing the role and function of online learning supervisors to improve the quality of learning practices and student learning outcomes in schools; (5) creating a pleasant climate for educators and educational staff as well as students..
\end{abstract}

Paper type: Research paper

Keyword: Principals as learning leaders, learning leadership, covid-19 pandemic.

Received: August $6^{\text {th }}, 2020$

Revised: September $17^{\text {th }}, 2020$

Published: September $30^{\text {th }}, 2020$

\section{INTRODUCTION}

The 2019 coronavirus disease pandemic or Covid-19(Joseph \& Ashkar (2020), Liang (2020) dramatically affects many people's lives, including school principals in leading learning in schools. The impact of Covid-19, in the short term, has disrupted schools globally. Almost all schools have been suspended, and the learning process has been adjusted in various ways. By designating Covid-19 as a shortterm crisis, it has been suggested that this critical opportunity to change schools and school systems for the better has its challenges and opportunities. The standard service is continued by allowing principals to lead more effectively to view current instructional leadership practices as temporary improvements. Before Covid-19, the type of leadership most often found in schools could be described as following the principal's roles and functions. The principal's core objective is basically to run the school and ensure that the learning process runs effectively and efficiently. Globally, learning leaders, at all levels in the educational delivery process, school principals spend their time influencing and engaging with others via laptop or mobile screens. They practice their leadership through a two-dimensional space. Learning leaders devote an hour or more 
carrying out their duties and functions through information and technology-based learning platforms, such as Teams, Zoom, or Google Meet (Harris, (2020), Trombly, (2020).

Principal learning leadership is an essential factor in realizing the success of school improvement and overall effectiveness. The school principal's principal responsibility is to promote learning and successful academic and non-academic achievement of all students. Principals can achieve their goal by focusing on education, encouraging communication, coordination, collaboration, and synergy, using data to improve learning, providing support, and aligning curriculum, assessment, and quality learning processes (Lunenburg \& Irby, 2006)

The public can see how a school principal leads his institution professionally to reveal the secrets of the school's goodness. The key to a school's success lies in the scientific abilities, learning leadership behavior, and the principal managerial system. Bafadal (2016) states that schools are complex and unique organizations requiring a high coordination level. The key to a school's success essentially lies in the efficiency and effectiveness of a principal's appearance. The success of the school is the success of the principal and vice versa. The principal is a leadership position that is not filled by people without being based on considerations. The job demands a vital leadership quality requirement (Bafadal, 2016). The reality in the field shows that it seems that not all teachers have the ability to carry out distance learning online learning) in full, including using distance or online learning platforms, such as (a) virtual learning; (b) e-learning; (c) Edmodo; (d) zoom meetings; (e) google classroom; (f) google meet (Anonymous, 2020).

First, the results of Hallinger (1992) show that there are 8.778\% of the aspects of the internal dimension that have not provided full support for the principal's learning leadership, both from indicators of school mission determination, learning arrangements, learning practices and from indicators of learning climate. Second, the research results of several researchers show that the potential for learning leadership is a significant role, but not the only role of leaders in schools (Hayes \& Irby, (2020), Zuckerman \& O'Shea, (2020), Baştuğ, Özdemir, Tanır, \& Salim, (2016). There are still roles of the principal, apart from being the learning leader. A principal is a teacher assigned to manage the school in the Regulation of the Minister of Education and Culture Number 6 of 2018. So it can be said that the principal's role is like two sides of a coin, first, as learning leaders in schools. Second, as a school manager. For this reason, it is expected that school principals will focus more on ensuring that all school activities refer to the National Education Standards.

The main question that arises is. The first question is, why do principals who have prominent learning leadership continue to exist in leading learning in schools during the spread of this coronavirus? Second, what things should the principal as the learning leader do to make students study comfortably and without the burden? This research was conducted to analyze the principal's role as a learning leader in the era of the Covid-19 pandemic.

\section{LITERATURE REVIEW}

Learning leadership is leadership that emphasizes learning. L.F., (1990),Sergiovanni, (1991), argues that effective learning leadership can be explained as follows. First, the meaning of the school's vision through sharing opinions with school members and striving for the school's vision and mission to thrive in its implementation. Second, school principals involve stakeholders in school management (participatory management). Third, the principal provides learning support. Fourth, the principal conducts monitoring of learning to understand more deeply and be aware of what is going on in the school. Fifth, the principal acts as a facilitator so that in various ways, he can identify learning difficulties and assist teachers in overcoming learning difficulties.

Hoy \& Miskel (2008) state that learning leadership is educational leadership that focuses on the core responsibilities, namely teaching and learning by promoting the school's vision, mission, and goals, managing learning programs, and promoting the school climate. The role of a learning leader is different from that of a traditional school administrator. Conventional school principals spend most of their time dealing with administrative duties. The principal is a leader who has a role to be the leading learner in the community to realize excellence in education. Thus, the principal is responsible for working with teachers to manage learning programs. As the learning leader, the principal knows what is happening in the classroom and develops the capacity of educators and education personnel. It is crucial to build strengths and reduce the weaknesses of educators and education personnel. Based on the description above, it can be understood that learning leadership is leadership that focuses on learning and has a vital concern for understanding, including professional education by teachers according to the development of students. This research is conducted to analyze the principal's role as a learning leader in the era of the Covid-19 pandemic. . 


\section{METHODOLOGY}

The research uses a qualitative approach with descriptive methods. Data are obtained through a literature review of various relevant literature and analyzed using a qualitative descriptive approach. .

\section{RESULTS AND DISCUSSION}

\section{Impact of Covid-19 in the Learning Process}

The impact of covid-19 in the learning process can be explained as follows. First, schools' learning activities are replaced with an online system or online learning to prevent covid-19 transmission. Second, the scheduled school final exam was finally decided to be abolished to save students from the spread of covid-19. Third, the large number of tasks given to students creates problems in the field, parents complain. On the other hand, teachers carry out functions according to the established curriculum. Fourth, learning about covid-19 can reduce the spread of the virus and reduce the impact of transmission of the covid-19 virus. Fifth, with the online learning system, (a) the learning process can take place and still exist; (b) students can study quietly at home; (c) teachers can provide subject matter well; (d) the principal can carry out his duties, functions, and roles in leading learning in school. Sixth, understanding of the Covid-19 virus is quickly understood, and the Covid-19 problem can be resolved immediately (Harris, (2020), Trombly (2020), StoneJohnson \& Miles Weiner (2020). From the description above, it can be understood that with the impact of covid-19, the learning process requires seriousness, accuracy, communication, coordination, synergy, and cooperation in responding to calls, regulations, and policies of the Government/Ministry of Education and Culture/ Education Office to prevent the spread of covid-19.

\section{What should the principal do as learning leaders during the Covid-19 Pandemic?}

During the Covid-19 pandemic, there are several things that the principal as the learning leader does. First, the principal conducts professional dialogue and discussions about learning. It can be done, among others (1) following appeals, regulations, and policies of the Government/Ministry of Education and Culture/ Education Office, namely learning is done through online learning; (2) coordination, communication, synergy, and collaboration with the teacher working group, the Principal Working Meeting, and school supervisors; (3) socialization with parents and students about how to deal with the coronavirus (covid-19) with materials that are appropriate to the age of the students.

Second, the principal provides an example or a model imitated by the teacher he leads. It can be done, among others, (1) giving motivation to teachers when giving assignments to students under the subjects and schedules that have been made; (2) providing data packages to students who cannot afford it so that online learning can be carried out and education reaches students; (3) providing a data package for teachers and the school's funding; (4) managing learning using online learning through applications: (a) virtual learning; (b) elearning; (c) Edmodo; (d) zoom; (e) google classroom; (f) google meet; (g) google hangout; (h) WhatsApp group; (i) Ministry of Education and Culture's learning house.

Third, school principals need to maintain close communication with teachers during their respective homes' online learning process. Technically, the implementation of learning can be done, among others (a) each teacher creates a WhatsApp group for each class that is the responsibility of the teacher; (b) the online learning process is carried out in the homes of both teachers and students through independent assignments; (c) when learning at home, the teacher makes online presence; (d) the learning process is reported to the principal in the form of a recap.

Fourth, the principal monitors and evaluates learning and uses the monitoring and evaluation results for further guidance. Technically this is done as follows (a) the principal conducts monitoring and evaluation of learning related to independent assignments that are given in a planned, programmed, and sustainable manner; (b) school principals coordinate with school supervisors starting from planning, implementing, and evaluating learning processes and outcomes in the form of a recap; (c) school supervisors follow up on findings in the field and the obstacles faced with online learning and independent assignments so that the learning process can run effectively and efficiently to prevent and overcome the spread of the Covid 19 disease.

In addition to doing the things mentioned above, the school principal also needs to pay attention to the following matters in carrying out his duties, functions, and roles as school principals related to learning during the Covid-19 pandemic. First, a form of distance learning (online) which is done by (a) doing homework in print; (b) doing homework in the form of a soft file via WhatsApp/telephone/email; (c) learning subject matter using video recordings; (d) learning online subject matter face-to-face with the teacher via video calls; (e) receive lesson material via chat/discussion on WhatsApp group. Second, the effectiveness of 
distance learning (online). Third, the limitations faced by teachers in carrying out distance learning (online): (a) preparing and compiling learning materials; (b) learning methods; (c) learning aids; (d) learning evaluation techniques; (e) internet connection; (f) learning time. Fourth, the limitations faced by students in carrying out distance learning (online): (a) internet connection; (b) finance for internet quota fees; (c) online learning methods; (d) online learning time: (e) direct communication with teachers; (f) online learning evaluation. Fifth, the assistance provided by the government to support the smooth implementation of distance learning (online) in schools: (a) training assistance for teachers to carry out online learning: (b) training assistance for students to carry out online learning; (c) internet quota fee assistance for teachers; (d) internet quota fee assistance for underprivileged students (Ministry of Religion, 2020; Hayes, \& Irby, 2020; Hallinger, 1992; Zuckerman \& O'Shea, 2020).

Furthermore, the efforts made regarding the role and function of the principal as a learning leader in schools can be explained as follows. First, the efforts made to improve the learning leadership behavior are carried out by (a) increasing the human resources of school principals through training, workshops, and so on, especially in understanding curriculum and addictive techniques; (b) empowering MKKS (Principal Working Meeting) to play a role in improving the human resources of school principals, especially in organizational learning.

Second, the efforts that the principal should make through his leadership, namely (a) empowering the potential of teachers in the learning process; (b) have an exact schedule for completing tasks; (c) establish healthy interpersonal relationships, act reasonably, effectively, efficiently, responsibly and accountably, and (d) work through a management team that involves all school components. Third, the government's efforts to optimize the leadership performance of school principals can be made through (a) establishing a school management laboratory; (b) recruitment of principals who are free from KKN; (c) a school principal career development system that provides opportunities to develop openly at local, regional and national levels.

Fourth, things that need to be done by the principal are (a) maintaining and improving the learning leadership behavior of the principal that has been implemented so far; (b) streamlining the implementation of classroom visit supervision as a means of fostering professional, social and personal skills of teachers by being more oriented towards teacher needs, so that management of class visits is not only based on the principal's initiative who tends to be needs-oriented as seen by the principal; (c) utilize external agents of the school, particularly the potential of school sciences, to participate in school development to enrich the insights and ideas for the future development of the school; (d) increasing the understanding of teachers through comparative study visits to schools that are considered good, outstanding, superior, and favorite and the like to study aspects of school management, particularly the power of teaching and learning activities. .

\section{CONCLUSION AND RECOMMENDATIONS}

Based on the above description, it can be concluded that, first, learning leadership is leadership that focuses on learning and has a vital concern for education, including professional education by teachers according to students' development. The principal's learning leadership behavior in improving student learning outcomes can be realized through his ability to set the school's vision and mission, organize learning, improve learning practices, and create a positive learning climate in schools.

Second, the impact of Covid-19 in the Learning Process, namely (1) eliminating learning activities in schools, replaced by an online system; (2) school final exams are canceled to save students from the spread of covid-19; (3) the number of tasks given to students, not a few parents complained; (4) learning about covid-19 can reduce the spread of the virus and reduce the impact of covid-19 virus transmission; (5) with the online learning system: the learning process can take place and still exist; students can study quietly at home; teachers can provide subject matter well; The principal can carry out his duties, functions, and roles in leading learning in school.

Third, the principal is done several things as a learning leader to prevent the impact of the spread of the corona (covid-19), namely. First, the principal conducts professional dialogue and discussions about learning during the Covid-19 pandemic. It can be done, among others (1) following the recommendations, regulations, and policies of the Government/Ministry of Education and Culture/Education Office, namely learning is carried out through online learning; (2) coordination, communication, synergy, and cooperation with teacher working groups, school principals and supervisors; (3) socialization with parents and students. Second, the principal provides an example or a model imitated by the teacher he leads. It can be done, among others, (1) giving motivation to teachers when giving assignments to students under the subjects and schedules that have been made; (2) providing data packages to students who cannot afford it so that online learning can be carried out and learning reaches students; (3) providing a data package for teachers and the school's funding; (4) 
managing learning by using online learning through applications. Third, school principals need to maintain close communication with teachers during their respective homes' online learning process. Fourth, the principal monitors and evaluates learning and uses the monitoring and evaluation results for further guidance.

The recommendations can be conveyed as follows. First, for school principals, they should (1) monitor school progress in a planned, programmed and sustainable manner in accordance with the school's vision; (2) be supportive and corrective when there are deviations in the implementation of activities that do not lead to the school's image; (3) manage the work structure of teachers and students, such as: the preparation of plans and learning objectives, grouping teachers into teams of subject teachers, grouping students into classes, determining class sizes, structuring the schedule structure, establishing a system for providing and sending the required learning resources teachers, as well as arrangements for implementing continuous learning evaluations in accordance with the appeal, regulations and policies of the Government/Ministry of Education and Culture/ Education Office regarding distance learning policies to prevent the spread of covid-19; (4) play more roles of online learning supervision in order to improve the quality of learning practices and student learning outcomes in schools; (5) create a pleasant climate for school staff (educators and education staff) and students; (6) pay attention to the following matters, namely: (a) the readiness of school infrastructure to conduct online distance learning; (b) implementation of distance learning (online) in schools; (c) delivery of online learning materials at schools; (d) teachers' skills for distance learning; (e) the technical ability of teachers to do distance learning (online); (f) distance learning (online) made by teachers (Ministry of Religion, 2020). What is good from these six factors needs to be maintained and even improved, and what is not good, it is necessary to find alternative solutions to make it better.

Second, there are recommendations for teachers. Teachers should (a) continue to innovate and be creative and contribute to efforts to realize superior and quality learning in the era of the Covid-19 pandemic; (b) upload and download the lesson plan adapted to the online learning system on the guruberbagi.kemdikbud.go.id page, which was launched on March 31, 2020; (c) continue to improve competence through education and training activities or non-education and training activities (webinars in the Covid-19 pandemic era, discussion of educational issues, seminars, workshops, research, writing books/ teaching materials, making learning media, technology/art creation).

\section{ACKNOWLEDGMENTS}

The paper has no conflict of interest.

\section{REFERENCES}

Anonymous. (2020). The Impact of Covid-19 on Education in Indonesia. (online),.

Bafadal, I. (2016). Assessment of Principal Performance as Learning Leaders in the Framework of School Accountability. Journal of Educational Management., 25(1), 1-9.

Baştuğ, G., Özdemir, M., Tanır, H., \& Salim, E. (2016). The Effect of Acute Weight Loss on Body Composition, Self-esteem and Appearance Esteem before Competitions. Journal of Education and Training Studies, 4(11), 206-212. https://doi.org/10.11114/jets.v4i11.1732

Hallinger, P. (1992). The Evolving Role of American Principals: From Managerial to Instructional to Transformational Leaders. Journal of Educational Administration, 30(3), 09578239210014306. https://doi.org/10.1108/09578239210014306

Harris, A. (2020). COVID-19 - school leadership in crisis? Journal of Professional Capital and Community, ahead-of-p(ahead-of-print). https://doi.org/10.1108/JPCC-06-2020-0045

Hayes, S. D., \& Irby, B. J. (2020). Challenges in preparing aspiring principals for instructional leadership: voices from the field. International Journal of Leadership in Education, 23(2), 131-151. https://doi.org/10.1080/13603124.2018.1562102

Hoy, W., \& Miskel, C. (2008). Educational Administration: Theory, Research, and Practice. New York: McGraw Hill.

Joseph, T., \& Ashkar, M. (2020). Covid-19: International Pulmonologist's Consensus on Covid-19. India: Amrita Institute of Medical.

L.F., R. (1990). The Principalship: Dimension in Instructional Leadership. Boston: Allyn and Bacon.

Liang, T. (2020). Handbook of Covid-19: Prevention and Treatment. Zhejiang: University School of Medicine.

Lunenburg, F. ., \& Irby, B. J. (2006). The Principalship: Vision to Action. United Kingdom: Wadsworth Cengage Learning. 
Sergiovanni, T. J. (1991). The Principalship: A Reflective Practice Perspective. Boston: Allyn and Bacon, Inc.

Stone-Johnson, C., \& Miles Weiner, J. (2020). Principal professionalism in the time of COVID-19. Journal of Professional Capital and Community, ahead-of-p(ahead-of-print). https://doi.org/10.1108/JPCC-052020-0020

Trombly, C. E. (2020). Learning in the time of COVID-19: capitalizing on the opportunity presented by the pandemic. Journal of Professional Capital and Community, ahead-of-p(ahead-of-print). https://doi.org/10.1108/JPCC-05-2020-0016

Zuckerman, S. J., \& O’Shea, C. (2020). Principals' Schema: Leadership Philosophies and Instructional $\begin{array}{llll}\text { Leadership. Journal of } & \text { School } & \text { Leadership, } & 105268462096606 .\end{array}$ https://doi.org/10.1177/1052684620966063 